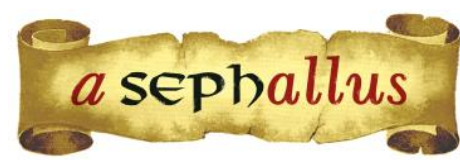

Revista aSEPHallus de Orientação Lacaniana

Núcleo Sephora de Pesquisa sobre o Moderno e o Contemporâneo

ISSN $1809-709 \mathrm{X}$

\title{
A.mor.te: Reflexões psicanalíticas sobre o amor e a morte na pandemia
}

Rebeca Espinosa Cruz Amaral ${ }^{1}$ Orcid: 0000-0001-5011-5226

Doutoranda em Teoria Psicanalítica pela Universidade Federal do Rio de Janeiro / UFRJ (Rio de Janeiro, Brasil) Mestre em Teoria Psicanalítica pela Universidade Federal do Rio de Janeiro / UFRJ (Rio de Janeiro, Brasil) Graduada em Psicologia pela Universidade Federal Fluminense / UFF (Campos dos GOytacazes, Rio de Janeiro,

E-mail: respinosacamaral@hotmail.com

\section{Danielle Desirée Souto Maior Cervino} Orcid: 0000-0002-0635-4630 Mestre em Teoria Psicanalítica pela Universidade Federal do Rio de Janeiro / UFRJ (Rio de Janeiro, Brasil) Psicóloga do Serviço de psicologia do Hospital Geral Glória D'Or - Rede D’Or Graduada em Psicologia pela Universidade Federal do Rio de Janeiro / UFRJ (Rio de Janeiro, Brasil)

E-mail: daniellecervino@yahoo.com.br

\begin{abstract}
Resumo: O que uma pandemia nos revela sobre as articulações entre o amor e a morte? Por que tememos a morte daqueles que amamos? Amor, morte e temor sempre estiveram presentes na clínica e nas elucubrações psicanalíticas, mas se tornaram palavras ainda mais rotineiras em hospitais e consultórios psicanalíticos num contexto pandêmico. A partir disso, visamos aqui, através de uma revisão bibliográfica que se deu a partir da experiência de escuta de pacientes e familiares principalmente num hospital, um estudo sobre as articulações entre amor e morte. 0 estudo desses temas nos mostra que eles estão imbricados na psicanálise orbitando ambos ao redor da falta e relacionadas ao desamparo. Esse delineamento, como veremos, é essencial para orientar o psicanalista em sua prática.
\end{abstract}

Palavras-Chave: Psicanálise; morte; amor; pandemia.

A.mor.te: Réflexions psychanalytiques sur l'amour et la mort dans la pandémie: Que nous révèle une pandémie sur les liens entre l'amour et la mort? Pourquoi craignons-nous la mort de ceux que nous aimons? L'amour, la mort et la peur ont toujours été présents dans la clinique et dans les explications psychanalytiques, mais ils sont devenus des mots encore plus courants dans les hôpitaux et cabinets psychanalytiques dans un contexte de pandémie. Dans cette optique, nous souhaitons ici, à travers une revue bibliographique issue de l'expérience d'écoute des patients et des membres de leur famille principalement dans un hôpital, étudier les articulations entre amour et mort. L'étude de ces thèmes nous montre qu'ils s'entremêlent dans la psychanalyse orbitant à la fois autour du manque et liée à l'impuissance. Cette conception, comme nous le verrons, est essentielle pour guider le psychanalyste dans sa pratique.

Mots clés: Psychanalyse; mort; amour; pandémie.

A.mor.te: Psychoanalytic reflections on love and death in the pandemic: What does a pandemic reveal to us about the links between love and death? Why do we fear the death of those we love? Love, death and fear have always been present in the clinic and in psychoanalytic explanations, but they have become even more routine words in psychoanalytic hospitals and offices in a pandemic context. With this in mind, we aim here, through a bibliographic review that took place from the experience of listening to patients and family members mainly in a hospital, to study the articulations between love and death. The study of these themes shows us that they are intertwined in psychoanalysis orbiting both around the lack and related to helplessness. This design, as we will see, is essential to guide the psychoanalyst in his practice.

Key words: Psychoanalysis; death; love; pandemic. 


\title{
A.mor.te: Reflexões psicanalíticas sobre o amor e a morte na pandemia
}

\author{
Rebeca Espinosa Cruz Amaral \& Danielle Desirée Souto Maior Cervino
}

\section{Introdução}

O que uma pandemia é capaz de nos revelar sobre o amor e a morte? O que tememos tanto com a morte daqueles que amamos? Amor, morte e temor, palavras que se tornaram cotidianas no contexto de uma pandemia, seja na rotina de hospitais, seja em consultórios psicanalíticos. Enganase, porém, quem acha que essas são novas para nós, psicanalistas. Há tempos as escutamos em diferentes contextos e, por isso, há muito elas fazem parte de nossas investigações. E aqui, mais uma revelação aos desavisados, elas estão sempre associadas. Prova disso é que a segunda teoria pulsional de Freud faz uma oposição justamente entre Eros e Tânatos, correlacionados justamente ao amor e à morte.

Freud muito se ocupa da temática da morte, principalmente por volta de 1915, ao presenciar os desdobramentos da Primeira Guerra Mundial. É nessa época que ele escreve textos como Reflexões para os tempos de guerra e morte (Freud, 1915/1996c), Sobre a transitoriedade (Freud, 1916 [1915]/1996d), Luto e Melancolia (Freud, 1917[1915]/1996e), e ainda, alguns anos depois, Além do Princípio do Prazer (Freud, 1920/1996f). Mas todos esses essencialmente trazem a marca de um escrito anterior, de 1914/1996, que podemos considerar um grande divisor de águas em suas teorizações. Trata-se de Sobre o Narcisismo: Uma introdução, texto onde a temática do amor assume tons de centralidade.

É curioso notar que Freud começa o texto de 1915/1996c dizendo que os tempos de guerra são tempos confusos, em que somos obrigados a acreditar em informações unilaterais, estamos próximos a grandes mudanças e sem conseguirmos vislumbrar o futuro - exatamente como temos escutado muitos dizerem a respeito dos nossos tempos de pandemia em 2020, cento e cinco anos depois, e em outro contexto. Seguindo sua ressalva, não podemos comparar este mal que nos assola hoje com males de outros tempos que não vivemos. Mas é notável que assim como ele descreve o indivíduo daquela época como sentindo-se "atônito em sua orientação e inibido em seus poderes e atividades" (Freud, 1915/1996c, p. 311), em função principalmente da desilusão provocada e da mudança de atitude diante da morte, podemos dizer o mesmo das pessoas atualmente. Assim como outrora, notamos que o sujeito hoje se sente "desamparado num mundo que se the tornou estranho" (Freud, 1915/1996c, p. 311).

Desamparo é aqui um ponto chave. No texto de 1914/1996b, Freud afirma que ao nascer a criança é, num primeiro momento, apenas um ser vivente. Encontra-se numa condição de desamparo em que não há um eu constituído e não é capaz de satisfazer suas necessidades, de modo que precisa de um outro - que inicialmente são seus pais - que exerça essa função. 
Assim se constroem suas primeiras relações libidinais com aqueles que assumem a posição de cuidála; serão esses que darão base à sua constituição, e aos seus futuros modos de enlaçamento, de relacionar-se com o outro. Ao longo de sua obra, e ainda depois com os posteriores avanços operados pela leitura de Jacques Lacan, fica mais claro como essa experiência originária e fundante é vivida pelo sujeito com intensa angústia por confrontá-lo com sua condição de falta-a-ser e com a ameaça de morte, colocando algo do real em jogo. Diante disto, assim como na infância, com frequência recorre-se ao outro e à construção de relações libidinais, como uma tentativa de resposta ao desamparo.

Este, porém, se faz sempre presente, fazendo com que as amarras simbólicas e imaginárias que se costuram para tentar tamponá-lo nunca consigam fazê-lo por completo. Não é à toa, por exemplo, que Lacan fala do amor, em 1972-1973/2008b, como uma ilusão. Entretanto, é fundamental esclarecer que a ilusão é necessária aos sujeitos, e isto Freud já afirmava demonstrando que esta é uma necessidade estrutural dos mesmos, justamente em razão de seu desamparo originário, e destes serem fadados ao encontro faltoso.

Assim, o estudo desses temas nos mostra que eles estão ainda mais imbricados na psicanálise quando notamos que amor e morte orbitam ambos ao redor de um conceito muito importante para nós, a falta. Em relação à esta, Lacan (1956-1957/1995) inicia o Seminário 4 fazendo uma explanação do que define como as três formas da falta: castração, privação e frustração. Resumidamente, podemos dizer que a castração é uma operação simbólica que se dirige ao objeto imaginário, ou seja, o falo, na medida em que o sujeito é impossibilitado de tê-lo; a privação se dá na relação real e se dirige ao objeto simbólico, de modo que aqui a falta, no real, representa um furo; e a frustração ocorre na relação imaginária dirigindo-se ao objeto real, de modo que o sujeito a vive como um dano na medida em que é privado do objeto que lhe deveria ter sido dado por alguém que supostamente o tinha, mas não o fez, de modo que seu desejo é impossibilitado de realização.

Isto faz notar que a falta está no cerne do processo de constituição do sujeito, sendo-lhe essencial, o que se reafirma ainda pelo que a teoria psicanalítica demonstra de sua função de mola do desejo. Este, porém, a relaciona a algo de insuportável, principalmente na pós-modernidade, tempo em que, segundo Coelho dos Santos (2019), estamos diante de um movimento de rejeição patológica da falta como causa de desejo e do impossível da satisfação absoluta frente a uma promessa (impossível de se cumprir) de satisfação e felicidade sem limites. Atrelado a isso, vemos que o sujeito contemporâneo é um sujeito que rechaça a falta e coloca em seu lugar sua fantasia de onipotência narcísica.

É no âmago deste cenário, então, que somos atingidos por uma pandemia. Um vírus que se espalha nos obrigando à mudança de nossas rotinas, atingindo a todos de diferentes formas, causando, ainda, a morte de milhares. Um vírus para o qual ainda não há uma vacina ou um remédio totalmente eficaz, e que parece que além de nos ferir biologicamente, vem nos ferindo 
narcisicamente. Carrega consigo a ameaça de morte da qual tanto tentamos nos furtar e nos confronta com um real cru, diante do qual, às pressas, tentamos fazer alguma elaboração. Ao tirar ou ao menos quase fazê-lo - a vida de outros amados pelo sujeito, parece lançá-lo em um abismo. É com essa realidade que os psicanalistas vêm se confrontando através da escuta de seus pacientes, principalmente no contexto de unidades hospitalares. $\mathrm{E}$ isto faz questionar: $\mathrm{O}$ que representa para o sujeito a ameaça de morte ou a de seu objeto amado? Como isso pode orientar o psicanalista na prática hospitalar? São essas algumas das questões que nos conduzem nesse trabalho e que buscaremos abordar nos itens que se seguem.

\section{Te.(a).mor - "Dr.a, pelo amor de Deus! Eu não quero morrer!"}

Ao postular as três fontes de mal-estar em 1930[1929]/1996k, Freud fala a respeito da decadência do próprio corpo, das desordens da natureza que podem se voltar contra nós, destrutivamente, e do relacionamento com os outros. Tais postulações trazem em si a marca de um real que remete ao nosso próprio desamparo, gerando, portanto, mal-estar. Foi em virtude desses sofrimentos ameaçadores que os homens aprenderam a moderar suas reivindicações de felicidade, se contentando em escapar ou sobreviver a eles. Por este viés sabemos que os desdobramentos de uma pandemia, como esta da Covid-19, são inúmeros, pois afetam não apenas o corpo com a propagação descontrolada de um vírus capaz de matar - o que desvela a face destruidora que a natureza pode ter -, mas também, e, inevitavelmente, impacta os laços sociais. Há um "real sem lei" que está mais ligado ao que é contingente do que à previsibilidade que as leis científicas buscam estabelecer (Miller, 2008), restando evidente o que há anos a práxis psicanalítica nos anuncia: que há um "mais além" que se furta à representação. É algo que sempre nos escapa revelando a face caótica e mortífera do real.

Atualmente, os meios de comunicação nos bombardeiam diariamente, quase que por 24 horas, com as mais diversas informações sobre a pandemia. Sabemos em tempo real os números de infectados, os números de mortos, as comoventes histórias de perdas, o que nos apontam para a total impotência do homem frente à morte. Tal situação acabou levando diversas pessoas a procurarem o hospital com crise de pânico, acreditando que estavam contaminadas e que morreriam ou matariam o outro pelo vírus.

Neste contexto, o corpo entra em cena como um objeto à mercê de um vírus que pode morrer ou matar. Um corpo que, segundo Lacan (1975-1976/2007), é a única consistência mental do falasser, cuja subsistência vem da crença, inexorável, que tem um corpo, quando na verdade não o tem, pois, o corpo escapa a todo instante.

É nessa dimensão real do corpo - dimensão daquilo que nos escapa - capaz de ser vislumbrada pela doença orgânica que percebemos que há um limite para o corpo, o limite da vida, ou seja, a morte. Circunstância que desvela a condição de desamparo do ser falante na qual não há 
recursos simbólicos para sustentar-se. Segundo Lacan (1959-1960/2008a), a morte é uma das poucas coisas do universo simbólico para a qual não há significante que a represente. Desta forma, a palavra é incapaz de promover sua significação. Da morte, podemos afirmar, não sabemos nada! Estamos completamente desamparados. Contudo, ainda assim, o mais irônico é que, por estarmos sujeitos à finitude, a vida pode ganhar um sentido.

Se por um lado o desamparo, que se inscreve como uma marca estrutural no sujeito, revela que o bebê humano nasce na mais absoluta prematuração física e psíquica, por outro evidencia sua total dependência do Outro. O Outro pode interpretar o apelo do bebê, alimentar, cuidar, nomear e espelhar sua imagem. É nas vicissitudes do encontro com o Outro que o bebê pode adquirir recursos simbólicos para amparar-se frente ao real.

O desamparo nos lembra que há um limite para a representação, que algo para além do sujeito escapa e somos impotentes frente a isso. Não é à toa que nessas circunstâncias a angústia surja como sinal de um real que invade o imaginário (Lacan, 1974-1975).

Esse desamparo, que é experimentado desde o momento do nascimento, resulta num aumento de excitação que se manifesta no corpo, só podendo ser eliminada através de uma experiência de satisfação; esta é aquela que resulta a partir do primeiro contato com o objeto, quando do encontro com o Outro, possibilitando assim a inscrição significante desse objeto na articulação entre sua imagem mnêmica com a acústica.

Vê-se que o investimento do Outro é essencial para a organização libidinal do bebê. Assim, é pelo desejo dos pais, estruturado em suas fantasias amorosas em relação ao filho - que nem nasceu, mas já é falado antes de falar - que a primeira forma de erotização do bebê ocorre na condição de objeto de amor. Tal investimento aplaca a pulsão de morte ligada ao desamparo primordial, fazendo operar, pelas vias do desejo do Outro, o princípio do prazer. Não é em vão que, sobre isto, Lacan (1962-1963/2005) irá dizer que "só o amor permite ao gozo condescender ao desejo" (p. 197).

Avançando em sua teoria, Freud (1920/1996f) transforma o que até então entendíamos como pulsões sexuais em Eros, sustentando que este, desde o princípio da vida, procura unir as substâncias vivas. Caracterizando-se como uma pulsão de vida, se opõe a Tânatos, uma pulsão de morte criada a partir da animação da substancia inorgânica.

Por ter isso em vista, muitos autores se referem a Eros como o que pode fazer frente à destruição, tendo, assim, certa função de proteção em relação à Tânatos, uma proteção do sexual em relação ao real. Por isso, o amor é visto como proteção à morte. Porém, há aí um paradoxo referente ao osso do erotismo, pois como mostra Freud em 1930[1929]/1996k, aquilo que nos protege do malestar, ao mesmo tempo é também fonte de um mal-estar.

Assim, não é sem conter, de alguma forma, a dimensão da morte que o amor se relaciona com ela, pois nas postulações de Freud (1930[1929]/1996k) já restava claro que mesmo a evolução 
da civilização sendo a representação entre a luta de Eros e Tânatos, uma pulsão inexiste sem a outra, pois elas estão em constante movimento de "fusionamento" e "desfusionamento".

Em que o amor e a morte se tocam mais diretamente é o que veremos a seguir, tendo como pano de fundo a situação atual da pandemia do Covid-19, que norteia esse trabalho, nos fazendo questionar o que entra em jogo para o sujeito quando experiência uma situação como essa.

\section{A.mor - "Dr.a, eu não posso morrer! 0 que será da minha família sem mim?"}

O trabalho dentro da UTI de um hospital geral, durante a pandemia, nos fez acompanhar alguns pacientes do início ao fim de seu tratamento e internação. Tal experiência mostrou que estar frente à morte gera impactos que afetam para além daqueles que estão passando por ela - a família e todos aqueles que amamos restam também afetados.

Nesse contexto, a todo momento se escuta de profissionais, familiares e pacientes, frases e relatos do tipo: "Tenho pânico de morrer desta doença e, pior, transmiti-la aos meus familiares e alguém morrer", "Dr. a, será que a culpa da morte da minha mãe é minha? Eu posso tê-la infectado", "Eu não posso morrer Dr.a, o que será da minha família sem mim?", "É cruel esse isolamento! Estamos totalmente no escuro sem podermos ver nosso pai!", "Por favor, posso enviar uma mensagem pelo WhatsApp ao meu filho? Sei que ele está intubado e sedado, mas tenho certeza que ele vai me ouvir!", "Dr.a, vc poderia tirar uma foto da minha irmã? Preciso ver se ela está mesmo viva, ainda que esteja intubada!".

Tais situações mostram que não somos abalados apenas pela possibilidade de nossa própria morte, mas também, e principalmente, pela morte daqueles que amamos. É como se a morte do outro também nos confrontasse com a ameaça da nossa própria. Talvez por isso Freud (1915/1996c) afirme que é ainda mais terrível quando essas mortes se dão em grande número. Com a guerra, segundo ele, e trazendo também para nosso contexto atual da pandemia, a situação se impõe de forma que a morte não pode mais ser negada ou ser tratada como algo fortuito. Embora Freud (1915/1996c) afirmasse que sobre nossa própria morte não queremos saber nada, é quando a ameaça recai sobre o objeto amado que mais nos sentimos atingidos por ela. Afirma que nesses casos:

Nossas esperanças, nossos desejos e nossos prazeres jazem no túmulo com essa pessoa, nada nos consola, nada preenche o vazio deixado pelo ente perdido. Comportamo-nos como se fôssemos um dos Asra, que morrem quando aqueles que eles amam também morrem. Mas essa nossa atitude para com a morte exerce poderoso efeito sobre nossas vidas. A vida empobrece, perde em interesse, quando a mais alta aposta no jogo da vida, a própria vida, não pode ser arriscada. Torna-se tão chã e vazia. (Freud, 1915/1996c, p. 328) 
Na tentativa de lançar luz a respeito dessa atitude, Freud recorre a hipóteses sobre a atitude do homem primevo frente à morte retomando um pouco da análise já efetuada por ele em Totem $e$ Tabu (1913[1912-1913]/1996a). Explica que para esse a morte de desconhecidos, muitas vezes considerados inimigos, era não só vista, como muitas vezes perpetrada. Mas, a sua própria morte, do mesmo modo que para os sujeitos atuais, era inimaginável. Estas duas atitudes opostas se conflitaram quando ele presenciou a morte de alguém que amava, de modo que a dor causada o fez confrontarse com o fato de que a morte estava posta para todos, fato contra o qual revoltou-se. Freud (1915/1996c) explica que a revolta que se desencadeia a partir desse fato se dá porque esse ente morto era, afinal, uma parte de seu próprio eu amado².

A análise de tal atitude é retomada por Freud em 1917[1915]/1996e, num texto destinado a tratar, como o próprio nome deixa claro, sobre os processos de Luto e Melancolia. Aqui, tentando fazer uma distinção entre os processos mentais envolvidos no trabalho de luto e no da melancolia, demonstra que ambos ocorrem frente à perda de um objeto de amor e provocam um profundo desânimo, inibição das atividades, perda de interesse pelo mundo externo e da capacidade de amar.

A respeito da melancolia, Freud apresenta uma particularidade: a diminuição da autoestima, que chega a se expressar como autorrecriminação e expectativa de punição. Assim, as perdas são momentâneas e compreensíveis, e se relacionam ao fato de que o mundo não evoca o objeto amado que, em contrapartida, nenhum outro objeto poderia substitui-lo. Mas, o que chama a atenção de Freud é que na melancolia - ao contrário de no luto quando fica evidente que a perda concerne ao mundo -, a perda parece referir-se ao próprio ego. Tal explicação está no fato de que a fala do paciente melancólico aponta para uma perda relativa a seu ego (Freud, 1917[1915]/1996e). Aqui, há uma condição psíquica relacionada à retirada da libido objetal de volta para o ego em virtude de uma perda de objeto. $\mathrm{O}$ que ocorre é que se estabelece uma identificação narcísica ao objeto amado em lugar de uma catexia erótica a ele dirigida.

Em seu texto sobre o narcisismo, Freud (1914/1996b) aborda a questão da escolha de objeto das crianças, observando que tais escolhas derivam de seus objetos sexuais em suas experiências de satisfação. Estas, inicialmente sendo autoeróticas, estavam ligadas à satisfação das pulsões do Eu, à sua autopreservação, só se separando desse alvo posteriormente, mas ainda mantendo com ele uma ligação que pode ser notada pelo fato de os primeiros objetos sexuais da criança serem as pessoas responsáveis por seus cuidados, alimentação e proteção. A esse tipo e fonte de ligação, Freud (1914/1996b) deu o nome de amor anaclítico ou de ligação, mas revelou existir além dele um tipo de escolha objetal que denominou de amor do tipo narcisista, pelo qual as pessoas procuram a si mesmas como objetos amorosos. Sobre estes, Freud (1914/1996b) afirma que, de acordo com os caminhos que levam à escolha de um objeto, uma pessoa pode amar: 1) Em conformidade com o tipo narcisista: o que ela própria é, o que ela própria foi, o que ela própria gostaria de ter sido, e, alguém que foi uma vez parte dela mesma; e, 2) Em conformidade com o tipo anaclítico (de ligação): a 
mulher que a alimenta e o homem que a protege. Acrescenta mais a frente que 0 apaixonamento se dá quando a libido do ego se direciona ao objeto e o exalta transformando-o num ideal sexual. Este é, assim, idealizado seja em função de satisfazer as condições infantis para amar - segundo a escolha objetal de tipo anaclítico - ou para satisfazer substitutivamente a satisfação narcísica que encontrou entraves - segundo a escolha objetal narcísica. Assim, o autor afirma que:

O que possui a excelência que falta ao ego para torná-lo ideal é amado. Esse expediente é de especial importância para o neurótico, que, por causa de suas excessivas catexias objetais, é empobrecido em seu ego, sendo incapaz de realizar seu ideal do ego. Ele procura então retornar, de seu pródigo dispêndio da libido em objetos, ao narcisismo, escolhendo um ideal sexual segundo o tipo narcisista que possui as excelências que ele não pode atingir. (Freud, 1914/1996b, p. 107)

Notamos, com isso, que as escolhas do objeto amoroso, sejam elas narcisistas ou anaclíticas, têm como matriz o narcisismo primário, relação originária marcada pela onipotência e completude. 0 amor é, assim, procurado por aqueles que renunciaram a uma parte de seu narcisismo e o transferiram para o objeto amado, como mostra Freud ao dizer que "o estar apaixonado consiste num fluir da libido do ego em direção ao objeto" (Freud, 1914/1996b, p. 107), ou seja, consiste na dinâmica entre a libido do eu e a objetal, através da qual a libido, antes totalmente dirigida para o eu, passa a dirigir uma parte de si aos objetos. Em função disto, Freud (1914/1996b) reafirmará que a escolha objetal é um passo adiante no desenvolvimento da libido, posterior ao estado narcísico.

Neste sentido, podemos afirmar que o amor se caracteriza pela supervalorização na medida em que o narcisismo infantil é transferido de certa forma ao objeto, ou seja, a libido passa a ser investida nos objetos enquanto idealizados. Em Psicologia de grupo e análise do ego, Freud (1921/1996h) esclarecerá isto melhor afirmando que a supervalorização do objeto amado à custa do amante pelo processo de idealização se dá em função do objeto amado ser colocado no lugar do ideal do eu.

Para avançar nessas questões é importante recorrermos à releitura lacaniana do narcisismo e de sua relação com o amor localizando-os centralmente no campo do imaginário, campo no qual se atesta certa ilusão de solda do significante com o significado, no sentido de uma suposta unidade. Ou ainda, como afirma Chemama (1995), é o registro que provém da constituição do corpo e deve ser entendido a partir da imagem e em suas relações com a identificação, acrescentando que é o "registro del yo [moi], con todo lo que este implica de desconocimiento, de alienación, de amor y de agresividad en la relación dual" (Chemama, 1995, p. 218)³.

Assim, após a releitura sobre o narcisismo e a constituição do eu efetuada em seu escrito $O$ estádio do espelho como formador da função do eu (Lacan, 1949/1998a), e em O Seminário, livro 1 (1953- 
1954/2009) Lacan faz algumas afirmações a respeito do amor associando-o a esta temática. Afirma que o amor é um fenômeno cujo fundamento acontece ao nível do imaginário e causa uma certa sobreposição do simbólico, por uma perturbação da função do ideal do eu. Segundo ele, no amor o objeto amado é equivalente ao ideal do eu pela captação que opera no sujeito, de modo que, como Freud, ele afirma que o amor reabre as portas à perfeição.

Esclarece ainda que o amor anaclítico (Anlehnung), assim como o amor narcísico, é também imaginário por estar fundado numa inversão de identificação na medida em que apesar de não amar diretamente pela via do tipo narcísico, o sujeito ama referenciado a uma situação primitiva, amando assim a mulher que o alimenta ou o homem que o protege. Isso o faz afirmar que nestes casos é também "o seu próprio eu que se ama no amor, o seu próprio eu realizado ao nível imaginário" (Lacan, 1953-1954/2009, p. 189).

É em virtude disto que podemos afirmar que o amor visa recuperar este estado de suposta unidade e completude do narcisismo primário para alcançar a suposta felicidade plena perdida. Alguns anos depois, Lacan (1972-1973/2008b) afirmará que Freud concebe o amor pela perspectiva do fazer Um, de uma fusão. Mas deixará claro que a fantasia de fazer Um a partir de dois é justamente o que o caracteriza como uma ilusão, pois esta é uma função impossível de cumprir.

É por isso que apontamos esse como o primeiro registro em jogo na demanda de familiares: querem ver seus amados, pedem fotos, vídeos, chamadas de vídeo, como se a imagem atestasse a constituição de seus corpos, afastasse a ameaça de separação e reestabelecesse ali alguma coisa. Suas demandas nos confrontam com o fato já apontado por Miller em sua leitura do Seminário 4, de Lacan (1956-1957/1995). Ele retoma a postulação deste autor de que a maior frustração é de amor e afirma que tudo que ele aponta em relação à frustração, volta às teorizações acerca da demanda, de modo que "demanda é o nome de batismo lacaniano da frustração" (Miller, 1995, p. 110). Mas o que mais precisamente está em jogo na frustração? Como explicamos na introdução de nosso trabalho, a frustração se dá na relação imaginária quando o sujeito se vê privado do objeto por alguém que ele acreditava ter para Ihe dar e não o fez, impossibilitando a realização de seu desejo. Com isso, neste campo, o sujeito se apresenta numa posição reivindicativa, apelativa, por crer que perdeu algo injustamente. Tal posição, vale destacar, parece intensificada nos dias atuais, em que a relação pósmoderna do sujeito com o Outro é marcada pelo engodo de uma relação dual, harmônica, na qual o Outro deve dar tudo ao sujeito e se não o faz é injusto, pois não pode haver falta, essa é rechaçada. O desamparo se tornou inadmissível em "benefício de uma vontade ilimitada de felicidade" (Coelho dos Santos, 2019, p. 27).

Desde as postulações lacanianas, porém, fica evidente que é preciso ultrapassar essa ordem apelativa. E será a tríade privação, frustração e castração que permitirá a ressignificação do imaginário pelo primado do simbólico. Prescindir do simbólico amarra o sujeito às garras de um 
imaginário atormentador. Quando se toma o real pelo imaginário, sem a mediação do simbólico, vê-se uma certa "perversalização" das relações; nestes casos, a falta de objeto é esfacelante para o sujeito.

Assim, é preciso que o simbólico regule o imaginário, tornando a frustração a introdução mais arcaica na ordem simbólica a partir da relação dual com a mãe. Através do atravessamento da frustração, o sujeito pode se desidentificar do falo e, deste modo, os objetos obtidos a partir do outro, antes compreendidos como reais, podem passar a ser apreendidos em termos de troca simbólica, sendo alçados à categoria de dom de amor. O Outro materno é, assim, simbolizado e transmite algo da ordem do desejo por suas ausências e presenças, o que permite que o sujeito simbolize algo da perda.

No Livro 4, de seus seminários, Lacan (1956-1957/1995) fala do amor em sua dimensão simbólica. Destaca a relação intrínseca entre o amor e a falta. 0 amor é compreendido como um dom que se recebe e que está diretamente ligado ao falo como falta. Para ele, este sentimento é uma significação que remete à incompletude do sujeito, ou seja, só ama quem dá o que não tem ou quem sente falta de alguma coisa, na medida em que o que se visa no amor é a falta - o falo. Lacan deixa isso bem claro ao trabalhar o caso freudiano sobre uma jovem homossexual (Freud, 1920/1996g), que não será abordado aqui, quando afirma que:

o que é, propriamente falando, desejado na mulher amada é justamente aquilo que lhe falta. [...]. No extremo do amor, no amor mais idealizado, o que é buscado na mulher é o que falta a ela. $O$ que é buscado, para além dela, é o objeto central de toda a economia libidinal: o falo (Lacan, 1956-1957/1995, p. 111).

Seguindo esta linha de pensamento, Lacan (1956-1957/1995) assevera ser por causa do falo, enquanto elemento imaginário, que o sujeito, no nível genital, é introduzido na simbólica do dom. Recorre, com isso, também à relação primordial da criança com a mãe, afirmando que esta é um agente instituído pela função do apelo. Por isso, tudo o que vem dela como resposta a ele é da ordem do dom, ou seja, algo situado para além do objeto. Em sequência a estas articulações, o autor afirma, ainda, que no interior da simbólica do dom podem ser dadas em troca toda a espécie de coisas, de modo que o que está em jogo na frustração é muito mais o dom - o amor de quem pode fazer este dom - do que o objeto. Assim, a frustração é de amor - recusa do dom enquanto símbolo do amor -, e quando realizada por algo que se refira à mãe, trata-se do que ele nomeia como frustração primitiva, sobre a qual diz:

Existe o objeto de que a criança é frustrada. Mas, depois da frustração, seu desejo subsiste. A frustração só tem sentido na medida em que o objeto, como pertinência do sujeito, subsiste 
depois da frustração. A mãe intervém, então, num outro registro: ela dá ou não dá, mas na medida em que esse dom é signo de amor. (Lacan, 1956-1957/1995, p. 142).

Para Lacan (1956-1957/1995), o pai é introduzido a partir desse momento como o mais-além da mãe imaginária. Ele intervém como função simbólica, ou seja, como aquele que pode dar o falo à criança, sendo sua potência nesse sentido, inconsciente. Deste modo, o autor afirma não existir maior signo de amor do que o dom daquilo que não se tem, acrescentando que a dimensão deste só se dá com a introdução da lei, ou seja, do simbólico, na medida em que a falta no Outro é fundamental à dimensão do amor.

A dimensão fálica é, assim, constitutiva do amor por não haver nada maior que o dom de sustentar a castração, visto que o amor só existe pela falta, pelo falo como correlativo do pai. Lacan (1956-1957/1995) acrescenta, assim, que o que estabelece a relação de amor entre dois sujeitos é que o dom é dado em troca de nada, pois "na medida em que, por detrás do que ele dá, existe tudo o que Ihe falta, é que o sujeito sacrifica para além daquilo que tem" (p. 143). Neste sentido, podemos dizer que o amor é dar um nada, um nada simbólico: o falo. $O$ falo reafirma a castração, pois o sujeito só pode declarar o seu amor na medida em que é incompleto.

Lacan (1956-1957/1995) afirma que o sujeito apreende a falta na experiência realizada durante a relação especular. Ou seja, o imaginário entra em jogo nas primeiras relações simbólicas entre o objeto criança e sua mãe, pois para ambos algo pode faltar imaginariamente. Assim,

É somente para além da realização narcísica, e na medida em que começa a se organizar a ida e vinda tensional, profundamente agressiva, do sujeito ao outro, em torno do que vão se infiltrar, se cristalizar as camadas sucessivas daquilo que irá constituir o eu, que pode se introduzir aquilo que faz surgir para o sujeito, para além do que ele próprio constitui como objeto para a mãe, esta forma em que o objeto de amor é tomado, cativado, retido, em alguma coisa que ele próprio relaciona à própria falta do objeto de amor. (Lacan, 19561957/1995, p. 180).

Com isso, Lacan (1956-1957/1995) postula que nenhuma satisfação obtida por intermédio de um objeto real, enquanto objeto próprio à urgência infantil, consegue preencher a falta. Deste modo, a falta está para além da falta que o objeto de amor "pode ser conduzido a substituir, a se propor ele mesmo como objeto que a preenche" (Lacan, 1956-1957/1995, p. 180).

Neste percurso sobre o amor, podemos dizer que se por um lado para Freud o sujeito ama tendo em vista um resgate de seu narcisismo primário, por outro Lacan dispõe que o amor é causa de desejo. Entendemos, assim, que este é estruturado a partir de um ideal de completude impossível de 
ser resgatado, mas podendo ser sublimado em objetos parciais de amor. Neste ínterim, questionamos: o que representa para o sujeito a ameaça de morte de seu objeto amado?

\section{Mor.te - "Tenho pânico de morrer desta doença, e pior, transmiti-la aos meus familiares e alguém morrer"}

Quando discorre sobre nossa atitude frente à morte, Freud (1915/1996c) nos diz que "no fundo ninguém acredita na própria morte; ou, o que vem a significar o mesmo, que no inconsciente cada um de nós está convencido de sua imortalidade" (p. 230). Entretanto, destaca em seu texto do ano anterior que "alguém que sofre de dor orgânica e más sensações abandona o interesse pelas coisas do mundo externo, na medida em que não dizem respeito ao seu sofrimento" (Freud, 1914/1996b, p. 26). Citando Wilhelm Busch quando fala do poeta que sofre de dor de dente - "No buraco de seu molar se concentra a sua alma" -, nos diz que quando o sujeito tem uma dor de dente, um mal de causa orgânica, inevitavelmente, seu mundo se reduz a um dente.

Esta lógica nos remete a pensar que diante da manifestação da dor no corpo - quando infectado por uma doença -, ou até mesmo da ideia de um corpo que pode vir a estar enfermo, o sujeito concentra sua vida nesta doença, neste corpo que toma status de objeto à mercê de uma finitude que lhe foge ao controle. O corpo que aqui é capaz de desvelar sua finitude, gera medo da morte e, portanto, surge como um real que angustia.

Ao formular seu conceito de pulsão de morte, Freud (1920/1996f) nos fala que embora a morte seja certa, uma vez que o objetivo de toda vida seja ela, o "organismo deseja morrer apenas do seu próprio modo" (p. 51). Daí resulta a afirmação do autor que "originalmente, esses guardiães da vida eram também os lacaios da morte" (Freud, 1920/1996f, p. 51), querendo dizer que se estabelece uma situação paradoxal resultante de uma espécie de "curto-circuito", pois os perigos que existem na vida que poderiam auxiliar o organismo a chegar mais rápido a seu objetivo são evitados. Sob essa perspectiva, correlaciona que há duas forças que mobilizam a vida: uma que institui a tendência do retorno ao inorgânico, e outra uma tendência à autopreservação. Quanto ao estado mais primitivo - que faz retornar ao estado inanimado -, é caracterizado como um empuxo à morte, cuja força indeterminada é fruto de uma tensão que deu origem à primeira pulsão, ou seja, a pulsão de morte. $O$ que não é igual para as pulsões sexuais que surgem sob aspecto muito diferente ${ }^{4}$, objetivando a conservação da vida - portanto, são pulsões de vida.

Ainda sobre a pulsão de morte, Freud (1920/1996f) destaca que é preciso uma certa dose de dimensão criativa para que ela possa encontrar um destino, conforme o exemplo das brincadeiras infantis. Lacan (1956-1957/1995), por sua vez, nos fala que a relação de objeto é criativa porque é na sua ausência, quando há a falta, que o sujeito pode buscar uma forma de simbolizar sua presença, reencontrando assim o objeto. E, sabemos que "no nível da experiência analítica, toda Findung encontro - do objeto, diz-nos Freud, é uma Wiederfindung - reencontro" (Lacan, 1956-1957/1995, p. 
52). Neste contexto, "reconhecemos, no entanto, como condição para a instalação da prova de realidade, que tenham sido perdidos os objetos que um dia trouxeram satisfação real" (Freud, 1925/1996j, p. 308).

Afirmando que é em torno da falta do objeto que podemos organizar a experiência de incorporação do significante, Lacan vai então descrever que "a cada vez que há crise, encontro, ação eficaz, no registro da busca de objeto, que é sempre, em si mesma, uma busca crítica" (19561957/1995, p. 54), há três níveis essenciais de situar a falta, castração, frustração, privação, das quais já falamos anteriormente.

Sobre isso, no texto $A$ negativa, Freud (1925/1996j) já falava que a própria estruturação da negação tem a ver com separação do objeto e o desamparo primordial, uma vez que o objeto reencontrado nunca mais será igual ao que foi perdido, nos deixando entregues à falta.

E é da falta de objeto que iremos abordar também a posição do sujeito em relação ao Outro, afinal, essas relações com o objeto só serão possíveis à medida que constituímos um Outro com o qual dialetizamos e nos referenciamos àquilo que nos falta, até porque a escolha de objeto também tem relação com o lugar de objeto que o sujeito foi para o Outro. "Sou ou não sou o que falta ao Outro?" "Tenho ou não tenho o que falta ao Outro?". Enfim, "o que o Outro quer de mim?". O que podemos perceber é que a constituição em torno da falta está diretamente ligada ao que é capaz de nos despertar desejo. Desejo que é desejo do Outro (Lacan, 1961-1962).

Podemos dizer que morte e vida se articulam a partir do momento em que possibilitam a falta e o desejo. O que, em linhas gerais, significa dizer que é do encontro com o Outro que o sujeito se constitui promovendo recursos simbólicos para que possa amparar-se.

A condição para o desejo é a falta que advém com a intervenção da lei, seja pela lei biológica que inscreve a condição de finitude dos seres vivos, ou pela lei simbólica, cuja incidência no sujeito promove um furo, limita o gozo e, por esta falta possibilita o desejo.

Em seu primeiro ensino, Lacan (1956-1957/1995) teoriza que o sujeito neurótico é aquele que se organiza submetendo-se à ordem simbólica, que marca uma falta-a-ser, um ser-para-a-morte, a morte simbólica, a castração. Essa submissão do sujeito que se dá quando de seu encontro com o Outro é o ponto de partida para sua relação com a falta de objeto.

A castração no neurótico promove uma interdição a partir de uma divisão no sujeito. Instaurase a lei que estabelece a falta e consequentemente advém o desejo, o que segundo Lacan (19621963/2005) ocorrerá pela queda do objeto $a$. Condições ligadas à posição do sujeito frente ao Outro, pois devido à esta separtição é que ele fica às voltas com a constante busca de um objeto que, supostamente, poderia completá-lo. O que fica evidente é que o desejo é ilusório, "porque sempre se dirige a um outro lugar, a um resto, um resto constituído pela relação do sujeito com o Outro que vem substituí-lo" (Lacan, 1962-1963/2005, p. 262). A este resto Lacan chamou de: objeto a da fantasia, "suporte do desejo" (Lacan, 1962-1963/2005, p. 194). Em outros termos: 
Um resto precário e submisso, sem dúvida, pois, como todos sabem hoje em dia, sou para sempre o objeto cedível, o objeto de troca, e esse objeto é o princípio que me faz desejar que me torna desejoso de uma falta - falta que não é uma falta do sujeito, mas uma carência imposta ao gozo situado no nível do Outro. (Lacan, 1962-1963/2005, p. 359).

A fantasia fundamental que supõe uma possibilidade de completude, em termos gerais, nada mais é do que a busca do sujeito em resgatar seu próprio narcisismo. Assim, se o sujeito em sua constituição, como vimos anteriormente, é dependente do investimento do Outro, investimento que em contrapartida também presume uma fantasia dos pais, o que entra em jogo aqui não é a necessidade do bebê, mas um mais além: o dom do amor que acreditamos que o Outro possa nos dar.

Tal ponto é importante para que possamos abordar não apenas a noção de amor, mas também a noção de morte para a psicanálise. Afinal, o que abala o sujeito em seu confronto com a morte? O que entra em jogo para ele?

Sobre a morte pressupõe-se duas experiências: uma é a falta real, e a outra a falta simbólica. A falta real é a que aponta para um limite no corpo que é irrepresentável, um furo, limite da vida, ligada à morte biológica - a primeira morte. Já a falta simbólica diz respeito à castração, ligada ao que Lacan (1959-1960/2008a), a partir da teoria sadiana, irá chamar de morte simbólica - a segunda morte.

O confronto com a possibilidade da própria morte ou da morte de quem amamos é uma situação capaz de gerar angústia ao sujeito. E, para a psicanálise "a angústia da morte (...) pode ser apreendida como elaboração da angústia de castração" (Freud, 1923/1996i, p. 73). Em termos gerais, o que significa, é que a morte biológica, a primeira morte, é aquela que se refere à privação da vida no real, já a castração nos remete à morte de uma posição simbólica na qual o sujeito se amparava frente ao real. Esta morte que aponta para a condição de desamparo primordial e fundamental da condição humana, desde seu nascimento, é que é a segunda morte.

Desenvolvemos anteriormente a ideia de que a morte nos coloca numa posição onde é possível desvelar a situação de desamparo a que todos nós estamos submetidos. Desamparo primordial que nos mostra o quanto a fragilidade da vida encontra-se subjacente à dependência do Outro. É um lugar, segundo Lacan (1959-1960/2008a), entre-duas-mortes, onde, por exemplo, o grito do bebê como apelo é transformado em demanda pelo Outro, ou seja, apelo inscrito na linguagem com a resposta desse Outro. Encontrar-se, então, num estado de desamparo é estar sem amparos simbólicos para responder aquilo que acossa no real.

Lacan (1959-1960/2008a) observa que a grande tragédia humana é que tal lugar é insustentável para todos nós meros mortais, uma vez que estamos fadados a nos alienarmos ao 
desejo do Outro, logo, é da queda dessa posição que nos localiza frente ao Outro que emerge o que Freud denomina de angústia de castração.

Na segunda morte o sujeito se vê obrigado a lidar com a ameaça de sua inscrição na linguagem, apontando para um mais além que é inacessível de dizer de si mesmo na relação significante. O sujeito está, assim, entregue ao automatismo mortífero da repetição - a pulsão de morte -, que está no campo do impossível de se inscrever, mas que, mesmo assim, é na repetição que o sujeito tenta dar conta disso que lhe escapa, buscando uma representação que por si só, já é a morte do símbolo, a morte da Coisa, uma morte simbólica, ou seja, a castração.

Portanto, a ameaça de morte de si e/ou do objeto amado traz a queda de uma fantasia onde o sujeito se localiza frente ao Outro numa posição simbólica. Uma posição que marca um ideal a ser atingido nessa estrutura fantasística. Esta, nada mais é do que a fantasia de completude na qual o sujeito vislumbra o resgate de seu narcisismo, dando ao outro o amor que idealiza e que the falta, esperando assim recebê-lo de volta. É este objeto que acreditamos ser parte de nós mesmos, ao qual damos o amor que não temos, esperando tê-lo de volta, que temos medo de perder frente à morte. Um objeto cujo o véu da fantasia nos posiciona, simbolicamente, frente ao Outro.

Destarte, se o amor implica nossa fantasia de ideal de completude nos posicionando frente ao Outro, e a morte é o que nos causa angústia de castração uma vez que vem abalar essa posição, como isso pode orientar o psicanalista na prática hospitalar?

\section{A.mor.te.ce.dor - "O isolamento é um ato de amor"}

Segundo a Organização Mundial de Saúde (OMS) uma pandemia caracteriza-se pela disseminação a nível mundial de uma nova doença. O surto afeta diversos continentes espalhando-se, descontroladamente, de pessoa para a pessoa, infectando toda a população.

Quando a declaração de pandemia foi determinada pela OMS, e paulatinamente diversos Estados foram seguindo esta determinação, muito pouco se sabia da doença e menos ainda sobre como proceder com o enfretamento dela. Os protocolos de saúde tiveram que ser elaborados na prática à medida que a doença e seus efeitos se espalhavam e a demanda hospitalar foi crescendo de forma exponencial.

Tal fato não foi diferente quanto à saúde mental. Sem a cura da doença e a globalização em tempo real das informações mundiais quanto aos infectados e mortos, milhares de pessoas entraram em pânico com a possibilidade da morte tão iminente, que desvelava de forma brutal o real de nosso desamparo primordial.

Com a pandemia veio a determinação de isolamento, do dia para a noite a rotina que construímos ao longo de nossas vidas, e que muitas vezes era motivo de reclamarmos por não termos tempo para nada, foi completamente modificada. O mais irônico é que aos isolados sobrava tempo, e por tal razão quadros de angústia, ansiedade e depressão surgiram uma vez que ninguém sabia o que 
fazer com ele. O tempo - vetor simbólico estruturado pelo homem -, continua a correr, nos lembrando que o temos para dar sentido à vida. Mas isolados, imobilizados de nossa rotina e tendo acesso ao Outro apenas por meios virtuais, a falta da falta se impõe por um real que invade o imaginário mostrando que sem a ordem simbólica não é possível viver.

Nesse contexto, também a equipe de psicólogos hospitalares teve que se reinventar. Quadriplicavam os números de atendimentos. A doença não apenas era caracterizada por seus sintomas orgânicos, mas com ela vinham diversos efeitos psicológicos. O combo promovido pela doença implicava o isolamento daqueles que amamos, a constante sensação da ameaça invisível do vírus, quase paranoica, pelo próximo ao nosso lado nas ruas, nos meios de transportes e até mesmo dentro de nossas casas, bem como a angústia pelo medo de morrer ou transmiti-la àqueles que amamos, podendo ocasionar sua morte.

Para atender tal situação que atravessava não apenas os pacientes infectados, mas também seus familiares e, principalmente, os profissionais de saúde, foi preciso adaptar os atendimentos aos meios de comunicação virtuais: proliferaram as chamadas de WhatsApp, as lives e as informações por redes sociais numa tentativa de fazer contorno a este real de difícil apreensão.

Nas situações mais graves, nas quais os pacientes encontravam-se intubados e impossibilitados de terem contato com seus familiares, o psicanalista era aquele que guiava, por sua voz, o olhar dos familiares a seus entes queridos internados. Fervilhavam perguntas do tipo: "- Dr.a, como ele está se alimentando? Ele está coberto? Ele está sentindo dor? Como está a cara dele? Você poderia dizer que todos estamos bem? Eu sei que ele vai escutar! A Dr. ${ }^{a}$ poderia fazer uma live com ele? Ou me enviar uma foto? Preciso ver como ele está.".

O questionamento sobre a impossibilidade de ver seus entes queridos era o mais recorrente. Haviam discursos de ignorância, raiva, medo e revolta. Eram constantes as insistências para visitá-los, principalmente, se o paciente evoluía para um estado grave que apontava para a possibilidade iminente de morte. Em alguns casos as falas dos familiares destacavam a crueldade que era serem impedidos de estarem ao lado daqueles que amam. Comumente, podíamos notar que uma intervenção produzia efeitos aplacando a angústia. A psicanalista respondia: "- 0 isolamento é um ato de amor! Um sacrifício em prol daqueles que amamos evitando levar outras doenças, germes e bactérias a um corpo tão debilitado. Ao mesmo que tempo que evitamos pegar a doença e transmitila a mais entes queridos".

Lacan (1974-1975) já avisava que o psicanalista é aquele que produz efeitos a partir de seu ato analítico e depois reflete e teoriza sobre eles. Assim é que nesse momento de escrita, a posteriori do ato, compreendemos os efeitos da intervenção analítica, que ao pontuar a necessidade do afastamento como prova de amor, permite que os sujeitos amem dando tudo que lhes falta e sacrificando para além do que tem. 
Com tudo isso, podemos perceber que a intervenção da analista permite aos sujeitos a apreensão do amor em sua relação com a própria falta de objeto, permitindo, assim, que se abram à dimensão do desejo, na medida em que diz Lacan (1958/1998b) que este não é nem o apetite da satisfação e nem a demanda de amor, mas sim o fenômeno da fenda que resulta da subtração do primeiro à segunda. Se sai, assim, do engodo do gozo pleno, e se permite uma libidinização do mundo, ao negativizar e esvaziar a dimensão imaginária do falo.

Em relação a isso, Lacan (1960-1961/2010) define o sujeito neste momento como falta-a-ser, pois seu ser não se encontra nos significantes que o representam, mas entre eles, ou seja, ele é onde falta, de modo que é como falta que ele apreende seu ser. O ser como absoluto, completo, é apenas um efeito imaginário, pois o sujeito da linguagem é dele separado, ou seja, ser falante é ser faltante, é falta-a-ser.

Mas por que tais efeitos puderam ser promovidos pelo psicanalista num contexto como esse? No avanço de seus estudos sobre o amor Lacan (1960-1961/2010) procede de modo particular a articulação do amor à condição desejante do sujeito, trabalhando centralmente o conceito de transferência, um dos princípios basilares e fundamentais da psicanálise. Para refletirmos sobre a dinâmica do amor e da fantasia iremos nos valer das considerações de Lacan acerca da transferência, onde ilustra de forma bastante exaustiva e pontual como se dá essa articulação.

Sobre a transferência, seus estudos perpassaram toda sua obra - como também ocorreu no decorrer das produções freudianas - e, ao longo desta, estiveram sempre articulados de alguma forma ao amor, a ponto de postular que transferência é amor e que "falar de amor, com efeito, não se faz outra coisa no discurso analítico" (Lacan, 1972-1973/2008b, p. 89) - o que também está relacionado ao fato de, assim como Freud, se deparar com esses impasses do amor na clínica pela fala de seus analisantes.

No coração de sua falta-a-ser o sujeito questiona-se sobre sua posição simbólica e, nesse momento, quando o sujeito procura análise, por exemplo, diante de um sofrimento, ele se endereça ao analista buscando a causa de seu sofrimento e supondo este saber ao analista. Ou ainda, podemos dizer, se endereça ao analista para que este, com seu saber, nomeie o objeto absoluto que completaria a falta no Outro.

Em termo gerais, a procura pela análise ocorre justamente pela recusa do sujeito que algo the falta. Em análise o sujeito pede, portanto, que o analista responda sobre seu ser e sobre o que falta ao Outro - demanda inerente ao complexo de castração -, e, com isso, sobre sua própria falta, como esclarece Lacan (1960-1961/2010). Instala-se, dessa forma, o sujeito suposto saber como pivô da transferência e condição de possibilidade da análise, surgindo o amor como significação ao vazio, endereçando-se ao analista por acreditar-se que ele possui o objeto procurado, a resposta sobre o seu ser. 
Entretanto, no contexto hospitalar, a demanda inicial do paciente que busca a instituição é formulada ao médico como uma demanda de cura, mas frente à impossibilidade da medicina ter uma resposta para tudo, a angústia surge de forma avassaladora. E ao sujeito só resta uma coisa: falar. Momento em que a demanda ao psicólogo hospitalar é formulada. Nos casos da Covid-19 percebemos que essa demanda de fala foi no intuito de tentar esvaziar a angústia que advém do isolamento do ente amado, supondo um saber ao psicanalista como sendo aquele que tem acesso tanto ao paciente quanto às informações sobre o seu estado de saúde, mas que também abre um espaço particular ao familiar para que possa falar.

O sujeito fará, então, ao analista uma demanda imaginária, atribuindo-lhe um lugar de objeto imaginariamente consiste, supondo-lhe um significante de seu ideal do eu, porém, este lhe responderá de um lugar simbólico, introduzindo uma dissimetria fundamental. O analista, como demonstra Lacan (1960-1961/2010), recusa o poder que the confere o estatuto de Outro, caindo do lugar do suposto saber como objeto-dejeto, um resto, o objeto a suporte da fantasia. Assim, passa a integrar a fantasia do analisando no lugar de objeto causa de desejo.

A esta demanda de amor, o analista responde com o seu desejo, remetendo o sujeito à falta estrutural do amor. Ele afirma, assim, que está ali não para o bem do analisando, mas para que ele ame, pois é assim que o analista aponta àquele que ama, através do amor de transferência, que há uma falta inscrita em seu desejo, colocando em jogo sua transmissão.

Neste sentido, vemos com Lacan (1960-1961/2010) que o amor de transferência traz uma relação de alienação necessária ao Outro, encarnado pelo analista, mostrando um aspecto da resistência que, paradoxalmente, permite a interpretação onde se vê o enlaçamento do desejo do sujeito e do desejo do analista. Este, portanto, é necessário para que haja relação transferencial e se situa na tensão entre a identificação idealizante (I) e o mote por onde o sujeito é levado a desejar, pela via do objeto causa de desejo (a), pois que ao se colocar no lugar de semblante, o analista provoca o aparecimento de um sujeito barrado. 0 desejo do analista provoca, pois, um corte para que o processo de identificação seja ultrapassado em direção ao atravessamento da fantasia, mantendo-se a distância entre o lugar da identificação idealizante e o lugar do objeto causa de desejo - objeto $a$.

A transferência, assim, segundo Lacan (1960-1961/2010) está submetida a uma ética que remete ao desejo do analista, o qual se posiciona em falta-a-ser, paga com sua pessoa abdicando de seu próprio desejo, se reduz a nada, traz em si o vazio que nunca deverá ser preenchido, condição de sua castração, de sua análise. Dessa forma, a direção da análise leva o sujeito a encontrar a falta no lugar do sujeito suposto saber, encontro que nada mais é do que do desejo por aquilo que ele é, falta. Ela implica em renunciar ao ser, ao gozo, e ficar com a castração, com o desejo.

Assim, mesmo que o que o sujeito tente constantemente seja restaurar, obturar a falta, aniquilá-la e recuperar o gozo interditado, reencontrar o mítico ser, de cujo gozo absoluto se foi apartado pela castração simbólica, pela inscrição do sujeito na linguagem, ser falante é ser falta-a-ser. 
E, somente em transferência o sujeito pode elaborar uma questão acerca de seu desejo a partir da operação pelo desejo do analista no lugar de não resposta, pois, ao cair da posição de sujeito suposto saber, o analista confronta o analisando com o saber inconsciente e o impossível de seu desejo.

Lacan (1960-1961/2010) considera, desta maneira, a transferência como semelhante ao amor por colocá-lo em causa. Ela se inicia com uma demanda de amor - que o autor entende também como demanda de reconhecimento do Outro -, mas resulta na colocação do sujeito no circuito desejante, passagem que a função do analista deve propiciar, barrando o excesso de plenitude narcísica e introduzindo a falta.

O amor, portanto, se liga à exigência de reconhecimento pelo Outro, mas não é idêntico às demandas que o assediam, estando para além delas. Por desconhecer o desejo do Outro, o sujeito é possuído pelo amor de transferência, cuja função, porém, é remeter ao desejo. Ao demandar que o Outro responda à sua falta-a-ser falando, esta emerge como desejo, ou seja, o desejo se articula na dependência da demanda. Será, então, no bojo dessas articulações que, alguns anos depois, Lacan (1962-1963/2005) irá formular que "só o amor faz o gozo condescender ao desejo" (p. 197).

Resumindo, para finalizar, no estabelecimento da relação transferencial, ao ser convocado a ocupar o lugar de sujeito suposto saber frente à demanda de saber e amor que the é endereçada pelo analisando, e responder com sua recusa, seu silêncio como interpretação, sua esquiva, ao se situar na posição de semblante do objeto causa de desejo, o analista possibilita que o sujeito se confronte com sua divisão, sua falta-a-ser, e, assim, o reenvia ao seu próprio desejo. É este o direcionamento de nosso trabalho clínico em consultórios e tem sido nas intervenções operadas no contexto hospitalar durante a pandemia, como relatado acima.

\section{Considerações Finais}

Conforme discorremos, o vírus da Covid-19 atingiu a população de forma avassaladora. Sua disseminação ocorreu de maneira exponencial, em escala mundial e de maneira muito rápida. A ciência, em uma corrida contra o tempo, empreende uma busca por respostas tentando chegar à cura da doença. Nesse contexto a doença não se restringe apenas aos sintomas orgânicos gerados aos infectados, mas causou também, à população, pânico, medo e angústias frente à possibilidade de morrer ou transmitir o vírus ao outro e matar.

Em meio a este panorama os profissionais da área de saúde tiveram que se adaptar na prática a esta nova situação sem precedentes. Se aos médicos, enfermeiros, fisioterapeutas, entre outros profissionais, que atuam numa Unidade de Terapia Intensiva (UTI), cabia a incumbência de promover o melhor tratamento, lidar com os sintomas orgânicos e buscar uma cura; por outro lado ao psicólogo cabia recolher os efeitos psíquicos nos sujeitos frente a esta situação.

No auge da pandemia os hospitais estavam lotados de pessoas infectadas para tratamento, mas também aumentou consideravelmente o número de pessoas com crise de pânico. Em ambas as 
situações duas questões se apresentavam na fala desses pacientes: o medo de morrer pela doença e o de matar um ente amado pela transmissão do vírus. Tal situação nos levou a questionar: $O$ que uma pandemia é capaz de nos revelar sobre o amor e a morte? O que representa para o sujeito a ameaça de morte a seu objeto amado? Como isso pode orientar o psicanalista na prática hospitalar? A partir do ensino de Freud e Lacan, bem como do aporte de autores contemporâneos, este trabalho realizou um percurso de pesquisa na tentativa de responder a tais questionamentos.

Iniciamos discorrendo sobre a questão do desamparo que a pandemia de uma doença orgânica desvelou ao nos confrontar com a dimensão real do corpo e seus limites, e, portanto, com a morte - uma das poucas coisas do universo simbólico, segundo Lacan (1959-1960/2008a), que não há significante que represente. $O$ desamparo, se por um lado se inscreve como uma marca estrutural no sujeito, revela que o bebê humano nasce na mais absoluta prematuração física e psíquica, por outro evidencia sua total dependência do Outro. Pois, é nas vicissitudes do encontro com o Outro que o bebê pode adquirir recursos simbólicos para amparar-se frente ao real. É frente ao desejo dos pais, estruturado em sua fantasia amorosa em relação ao filho, que a primeira forma de erotização do bebê ocorre nessa condição de objeto de amor.

Tal apontamento nos levou a buscar o conceito de amor para a psicanálise. Tecemos as considerações de que se por um lado para Freud o sujeito ama tendo em vista um resgate de seu narcisismo primário, por outro Lacan confirma isso, mas aponta para sua dimensão de troca simbólica e o relaciona ao desejo. Assim, se o sujeito em sua constituição, como vimos, é dependente do investimento do Outro, investimento que em contrapartida também presume uma fantasia dos pais, o que entra em jogo aqui não é a necessidade do bebê, mas um mais além; o dom do amor que acreditamos que o Outro possa nos dar. Então, se o amor envolve uma fantasia de completude com o objeto amado, o que entra em questão para o sujeito quando este resta ameaçado de morte?

Sobre a morte, Lacan, com base em sua leitura freudiana, expõe que se pressupõe duas experiências: uma é a falta real, e a outra a falta simbólica. O confronto com a possibilidade da própria morte ou da morte de quem amamos é uma situação capaz de gerar angústia ao sujeito onde ambas estão envolvidas, a morte biológica, a primeira morte, referente à privação da vida no real, e a morte de uma posição simbólica na qual o sujeito se amparava frente ao real - esta última, apontando para a condição de desamparo primordial da condição humana. Isto, pois, a ameaça de morte de si e/ou do objeto amado aponta para a invasão do real ao imaginário, momento no qual a angústia que advém sinaliza a queda de uma fantasia onde o sujeito se localizava frente ao Outro, numa posição simbólica. Uma posição que marca um ideal a ser atingido nessa estrutura fantasística ligada à fantasia de completude na qual o sujeito vislumbra o resgate de seu narcisismo por meio do amor. 
Tendo isso em vista, nos questionamos: Se o amor implica nossa fantasia de ideal de completude nos posicionando frente ao Outro, e a morte é o que nos causa angústia de castração uma vez que vem abalar essa posição, como isso pode orientar o psicanalista na prática hospitalar?

Nos casos da Covid-19 percebemos que a demanda de fala dos familiares apresentou-se em diversos casos no intuito de tentar esvaziar a angústia que advém do isolamento do ente amado e atrelada à suposição de um saber ao analista quanto ao paciente. Frente a isso, nos utilizamos de uma intervenção analítica, cujos efeitos se mostraram positivos em diversos casos que envolviam o questionamento de familiares sobre a impossibilidade de ver seus entes queridos enfermos. Trata-se da fala da analista que o isolamento era um ato de amor, um sacrifício em prol daqueles que eram amados. Comumente, podíamos notar que essa intervenção produzia efeitos aplacando a angústia, e compreendemos que ao pontuar a necessidade do afastamento como prova de amor, inclui-se a dimensão da simbólica do dom que marca para os sujeitos a castração e os inscreve no universo das trocas simbólicas, para além das reivindicações imaginárias, permitindo uma abertura à dimensão do desejo.

Assim, concluímos o trabalho observando que no contexto hospitalar durante a pandemia da Covid-19 o analista foi convocado a ocupar o lugar de sujeito suposto saber frente à demanda principalmente - de familiares de sujeitos acometidos por esta enfermidade e relançados às suas condições de desamparo frente à possibilidade de morte de um objeto de amor. Entretanto, foi sua recusa em atender às demandas destes que pôde operar um furo castrativo permitindo um deslizamento da posição de frustração imaginária e confrontando o sujeito com sua implicação em seu desejo.

\section{Notas}

1. Este artigo encontra-se vinculado à pesquisa de doutoramento em Teoria Psicanalítica/UFRJ de Rebeca Espinosa Cruz Amaral, orientada pela Profa. Dra. Tania Coelho dos Santos e conta com financiamento da Capes.

2. Não podemos desconsiderar o apontamento feito por Freud aqui de que apesar dessa atitude de revolta frente a morte de alguém amado, por outro lado, essa morte também agradava o homem primevo em função de essas pessoas amadas carregarem também algo de estranho, motivo pelo qual também despertavam sentimentos hostis, demonstrando a ambivalência que está sempre em jogo, e rege até hoje às relações emocionais com os amados.

3. Tradução nossa: o registro do eu, com tudo que ele implica de desconhecimento, de alienação, de amor e de agressividade na relação dual.

4. "Os instintos que cuidam dos destinos desses organismos elementares que sobrevivem à totalidade do indivíduo, que lhes fornecem um abrigo seguro enquanto se acham indefesos contra os estímulos do mundo externo, que ocasionam seu encontro com outras células 
germinais etc., constituem o grupo dos instintos sexuais. São conservadores no mesmo sentido dos outros instintos porque trazem de volta estados anteriores de substância viva; contudo, são conservadores num grau mais alto, por serem peculiarmente resistentes às influências externas; e são conservadores ainda em outro sentido, por preservarem a própria vida por um longo período. São os verdadeiros instintos de vida" (Freud, 1920/1996f, p. 50).

\section{Referências Bibliográficas}

Chemama, R. (1995). Diccionario Del psicoanálisis. Buenos Aires: Amorrotu editores.

Coelho dos Santos, T. (2019). O que é e onde começa a pós-modernidade? In T. Coelho dos Santos, A. L. Santiago, \& F. Oliveira. (Orgs.); Reconfigurações do Imaginário no Século XXI. (pp. 1731). Curitiba: CRV.

Freud, S. (1996a). Totem e Tabu. In J. Salomão (Trad.) Edição standard brasileira das obras psicológicas completas de Sigmund Freud (Vol. 13, pp. 11-125). Rio de Janeiro: Imago. (Trabalho publicado em 1913[1912-1913]).

Freud, S. (1996b). Sobre o narcisismo: Uma introdução. In J. Salomão (Trad.) Edição standard brasileira das obras psicológicas completas de Sigmund Freud (Vol. 14, pp. 77-108). Rio de Janeiro: Imago. (Trabalho publicado em 1914).

Freud, S. (1996c). Reflexões para os tempos de guerra e morte. In J. Salomão (Trad.) Edição standard brasileira das obras psicológicas completas de Sigmund Freud (Vol. 14, pp. 285312). Rio de Janeiro: Imago. (Trabalho publicado em 1915).

Freud, S. (1996d). Sobre a transitoriedade. In J. Salomão (Trad.) Edição standard brasileira das obras psicológicas completas de Sigmund Freud (Vol. 14, pp. 315-319). Rio de Janeiro: Imago. (Trabalho publicado em 1916[1915]).

Freud, S. (1996e). Luto e melancolia. In J. Salomão (Trad.) Edição standard brasileira das obras psicológicas completas de Sigmund Freud (Vol. 14, pp. 249-263). Rio de Janeiro: Imago. (Trabalho publicado em 1917[1915]).

Freud, S. (1996f). Além do Princípio do Prazer. In J. Salomão (Trad.) Edição standard brasileira das obras psicológicas completas de Sigmund Freud (Vol. 18, pp. 17-72). Rio de Janeiro: Imago. (Trabalho publicado em 1920).

Freud, S. (1996g). Psicogênese de um caso de homossexualismo numa mulher. In J. Salomão (Trad.) Edição standard brasileira das obras psicológicas completas de Sigmund Freud (Vol. 18, pp. 149-175). Rio de Janeiro: Imago. (Trabalho publicado em 1920).

Freud, S. (1996h). Psicologia de grupo e análise do ego. In J. Salomão (Trad.) Edição standard brasileira das obras psicológicas completas de Sigmund Freud (Vol. 18, pp. 75-146). Rio de Janeiro: Imago. (Trabalho publicado em 1921). 
Freud, S. (1996i). O ego e o id. In J. Salomão (Trad.) Edição standard brasileira das obras psicológicas completas de Sigmund Freud (Vol. 19, pp. 13-82). Rio de Janeiro: Imago. (Trabalho original publicado em 1923).

Freud, S. (1996j). A negativa. In J. Salomão (Trad.) Edição standard brasileira das obras psicológicas completas de Sigmund Freud (Vol. 19, pp. 261-269). Rio de Janeiro: Imago. (Trabalho original publicado em 1925).

Freud, S. (1996k). O mal-estar na civilização. In J. Salomão (Trad.) Edição standard brasileira das obras psicológicas completas de Sigmund Freud (Vol. 21, pp. 27-148). Rio de Janeiro: Imago. (Trabalho original publicado em 1930[1929]).

Lacan, J. (1961-1962). O Seminário, livro 9: a identificação. Rio de Janeiro: Jorge Zahar. (Trabalho inédito).

Lacan, J. (1974-1975). O Seminário, livro 22: R.S.I. Rio de Janeiro: Jorge Zahar. (Trabalho inédito).

Lacan, J. (1995). O Seminário livro 4: a relação de objeto. Rio de Janeiro: Jorge Zahar. (Trabalho original publicado em 1956-1957).

Lacan, J. (1998a). O estádio do espelho como formador da função do eu. In Escritos. Rio de Janeiro: Jorge Zahar. p. 96-103. (Trabalho original publicado em 1949).

Lacan, J. (1998b). A significação do falo. In Escritos. Rio de Janeiro: Jorge Zahar. p. 692-703. (Trabalho original publicado em 1958).

Lacan, J. (2005). O Seminário, livro 10: a angústia. Rio de Janeiro: Jorge Zahar. (Trabalho original publicado em 1962-1963).

Lacan, J. (2007). O Seminário, livro 23: o sinthoma. Rio de Janeiro: Jorge Zahar. (Trabalho original publicado em 1975-1976).

Lacan, J. (2008a). O Seminário, livro 7: a ética da psicanálise. Rio de Janeiro: Jorge Zahar. (Trabalho original publicado em 1959-1960).

Lacan, J. (2008b). O Seminário, livro 20: mais, ainda. Rio de Janeiro: Jorge Zahar. (Trabalho original publicado em 1972-1973).

Lacan, J. (2009). O Seminário, livro 1: os escritos técnicos de Freud. 2. ed. Rio de Janeiro: Jorge Zahar. (Trabalho original publicado em 1953-1954).

Lacan, J. (2010). O Seminário, livro 8: a transferência. 2. ed. Rio de Janeiro: Jorge Zahar. (Trabalho original publicado em 1960-1961).

Miller, J-A. (1995). A lógica na direção da cura. Minas Gerais: Seção Minas Gerais da Escola Brasileira de Psicanálise do Campo Freudiano.

Miller, J-A. (2008). $O$ real no século XXI, Recuperado de https://www.wapol.org/pt/articulos/Template.asp?intTipoPagina=4\&intPublicacion=38\&intEdic ion=13\&intIdiomaPublicacion=9\&intArticulo $=2493 \&$ intIdiomaArticulo $=9$ 
Citação/Citation: Espinosa Cruz Amaral, R., Desirée Souto Maior Cervino, D. (mai. 2020 a out. 2020). A.mor.te: Reflexões psicanalíticas sobre o amor e a morte na pandemia. Revista aSEPHallus de Orientação Lacaniana, 15(30), 56-79. Disponível em www.isepol.com/asephallus. Doi: 10.17852/1809709x.2020v15n30p56-79

Editor do artigo: Tania Coelho dos Santos.

Recebido/Received: 04/03/2020 / 03/04/2020.

Aceito/Accepted: 04/20/2020 / 20/04/2020.

Copyright: (C) 2019 Associação Núcleo Sephora de Pesquisa sobre o moderno e o contemporâneo. Este é um artigo de livre acesso, que permite uso irrestrito, distribuição e reprodução em qualquer meio, desde que o autor e a fonte sejam citados/This is an open-access article, which permites unrestricted use, distribution, and reproduction in any medium, provided the author and source are credited. 